\title{
OPINI AUDIT GOING CONCERN: SUDUT PANDANG LIKUIDITAS, LEVERAGE, FINANCIAL DISTRESS RISK, TAX RISK
}

\author{
Yogy Wira Utama1, Ahmad Syakur ${ }^{2}$, Amrie Firmansyah ${ }^{3}$ \\ Politeknik Keuangan Negara STAN \\ amrie@pknstan.ac.id
}

\begin{abstract}
This study examines the effect of liquidity, leverage, financial distress risk, and tax risk on going concern audit opinion acceptance. The method used in this study uses a quantitative approach. This study's population are all financial sector companies listed on the Indonesia Stock Exchange up to December 31th, 2019. Based on the purposive sampling method carried out for the observation year from 2017 up to 2019, the total sample selected is 84 observations. To test the hypothesis, this study uses logistic regression analysis. The results suggest that liquidity is negatively associated with going concern audit opinion, and financial distress risk is positively associated with going concern audit opinion. Meanwhile, the leverage and tax risk are not considered in providing a going concern audit opinion. As the capital market supervisory agency, this study indicates that the Indonesia Financial Services Authority needs to supervise companies with a going concern audit opinion to improveinvestor protection in the capital market.
\end{abstract}

Keywords: Financial Distress Risk, Going Concern, Leverage, Liquidity, Tax Risk.

\section{ABSTRAK}

Penelitian ini bertujuan untuk menguji pengaruh likuiditas, leverage, financial distress risk, dan tax risk terhadap penerimaan opini audit going concern. Metode yang digunakan dalam penelitian ini menggunakan pendekatan kuantitatif. Populasi dalam penelitian ini adalah seluruh perusahaan sektor keuangan yang terdaftar di Bursa Efek Indonesia sampai dengan 31 Desember 2019. Berdasarkan metode purposive sampling yang telah dilakukan untuk tahun observasi dari tahun 2017 sampai dengan 2019, total sampel terpilih berjumlah 84 observasi. Untuk menguji hipotesis, penelitian ini menggunakan analisis regresi logistik. Hasil penelitian menunjukkan bahwa likuiditas berpengaruh negatif terhadap opini audit going concern dan financial distress risk berpengaruh positif terhadap opini audit going concern. Sementara itu, leverage dan tax risk tidak menjadi pertimbangan auditor dalam memberikan opini audit going concern. Penelitian ini mengindikasikan bahwa Otoritas Jasa Keuangan selaku lembaga pengawas pasar modal perlu melakukan pengawasan kepada perusahaan-perusahaan yang memiliki opini audit going concern dalam rangka untuk meningkatkan perlindungan investor di pasar modal.

Kata kunci: Financial Distress Risk, Going Concern, Leverage, Liquidity, Tax Risk. 


\section{Pendahuluan}

Suatu perusahaan tidak selamanya berada dalam performa baik atau selalu memperoleh keuntungan yang tinggi dalam aktivitas operasinya. Dalam kondisi tertentu, perusahaan dapat mengalami masa-masa sulit sehingga mengakibatkan kelangsungan hidup perusahaan menjadi terganggu. Terdapat beberapa faktor yang mengakibatkan kondisi perusahaan tersebut seperti perekonomian, nilai tukar mata uang, kendala internal perusahaan, atau tidak tersedianya modal (Ningtias \& Yustrianthe, 2016).

Kelangsungan usaha perusahaan atau going concern merupakan salah satu asumsi dalam pelaporan keuangan. Perusahaan dengan kemampuan going concern yang baik berarti secara operasional memiliki kemampuan untuk mempertahankan hidup dan melanjutkan usahanya di masa depan. Going concern suatu perusahaan merupakan hal yang penting bagi stakeholders terutama bagi investor karena investor akan memiliki penilaian tentang kemampuan perusahaan dalam mempertahankan usahanya sebagai pertimbangan dalam membuat keputusan investasi (Ginting \& Tarihoran, 2017). Oleh karena itu, pemberian opini going concern menjadi salah satu aspek penting bagi manajemen perusahaan terutama bagi perusahaan yang terdaftar dalam pasar modal.

Pasar modal merupakan suatu pasar dimana terdapat berbagai jenis instrumen keuangan jangka panjang yang dapat diperjualbelikan meliputi ekuitas (saham), obligasi, reksa dana, instrumen derivatif dan instrumen lainnya. Bursa Efek Indonesia (BEI) menjadi pasar modal di Indonesia yang mempertemukan investor dengan perusahaan terbuka. Saat ini, perusahaan yang tercatat di BEI terbagi ke dalam sembilan sektor, yakni sektor pertanian (agriculture), pertambangan (mining), industri dasar dan kimia (basic industry and chemicals), aneka Industri (miscellaneous industry), industri barang konsumsi (consumer goods industry), properti, real estat dan konstruksi bangunan (property, real estate, and building construction), infrastruktur, utilitas \& transportasi (infrastructure, utilities, and transportation), keuangan (finance), serta perdagangan, jasa \& investasi (trade, service, and investment).

Fenomena yang terjadi saat ini, terdapat beberapa perusahaan di sektor keuangan yang mengalami permasalahan terkait going concern yang ditandai dengan penurunan kinerja keuangan. Meskipun menjadi salah satu sektor yang diminati para investor dalam menanamkan modalnya, sektor keuangan termasuk sektor yang rentan terdampak perlambatan ekonomi global.

Hal ini terbukti saat terjadi krisis ekonomi global tahun 2008, dimana salah satu bank di Indonesia ditetapkan sebagai bank gagal berdampak sistemik dan 
harus dilakukan mekanisme penyelamatan dalam skema bailout untuk menjaga stabilitas sistem keuangan (Rahadiyan, 2016). Contoh lainnya adalah Bank Muamalat mencatatkan perolehan laba 8 bulan pertama terendah setidaknya dalam 4 tahun sampai dengan tahun 2019 yang disebabkan oleh kesalahan strategi dalam menyalurkan pembiayaan (www.cnbcindonesia.com).

Konsentrasi penyaluran pembiayaan yang lebih berfokus kepada korporasi mengakibatkan pembiayaan bermasalah atau non performing financing bank tersebut meningkat. Hal tersebut semakin menambah isu menurunnya kepercayaan investor yang sudah ada sejak tahun 2015 (www.cnbcindonesia.com). Selain itu, kebutuhan masyarakat dalam hal pembiayaan yang semakin tinggi juga memunculkan beberapa kasus wanprestasi debitur dalam perjanjian pembiayaan yang merugikan perusahaan pembiayaan. Beberapa kondisi ini yang mengakibatkan perusahaan sektor keuangan berpotensi mengalami financial distress dan diragukan kemampuan going concern-nya.

Informasi kelangsungan perusahaan menjadi penting bagi pengguna laporan keuangan dalam pengambilan keputusan. Kelangsungan perusahaan erat kaitannya dengan pengelolaannya yang dilakukan oleh manajemen. Manajemen yang memiliki informasi lebih banyak terkait kondisi perusahaan dibandingkan dengan pemilik perusahaan mengakibatkan adanya informasi asimetri antara manajemen dan pemegang saham.

Strategi yang digunakan manajemen dalam menjalankan perusahaan menentukan keberhasilan suatu perusahaan. Lemahnya monitoring dari pemegang saham dapat berakibat manajemen menjalankan strategi bisnis perusahaan sesuai dengan diskresi yang dimiliki oleh manajemen. Strategi yang kurang sesuai dapat berakibat kelangsungan usaha dari suatu perusahaan menjaditerancam.

Auditor memiliki peran untuk mengungkapkan kepastian kondisi perusahaan di masa depan melalui opini audit going concern. Opini tersebut menunjukkan bahwa manajemen perlu melakukan perbaikan aktivitas operasinya apabila perusahaan ingin melanjutkan usahanya di masa mendatang. Oleh karena itu, ulasan atas opini audit going concern perlu untuk diinvestigasi lebih lanjut.

Penelitian ini bertujuan untuk menguji pengaruh likuiditas, leverage, financial distress risk, dan tax risk terhadap opini audit going concern. Likuditas, leverage, financial distress risk menunjukkan kondisi internal perusahaan, sedangkan tax risk merupakan respon investor dalam menghadapi kondisi eksternal perusahaan yang diakibatkan oleh ketidakpastian pajak (Firmansyah \& Muliana, 2018). Likuiditas merupakan kemampuan perusahaan dalam memenuhi seluruh 
kewajiban keuangan yang segera dapat dicairkan atau yang telah jatuh tempo (Hani, 2015). Secara spesifik, likuiditas mencerminkan ketersediaan dana yang dimiliki perusahaan untuk memenuhi semua utang yang akan jatuh tempo.

Kasmir (2016) menyatakan bahwa likuiditas sebagai ukuran kemampuan perusahaan dalam memenuhi kewajiban jangka pendek. Menurut Fahmi (2014), likuiditas mencerminkan kemampuan suatu perusahaan dalam memenuhi kewajiban jangka pendeknya secara tepat waktu yang penting untuk diperhatikan karena kegagalan dalam memenuhi kewajiban tersebut dapat menyebabkan kebangkrutan perusahaan. Islami dan Isynuwardhana (2019) mendeskripsikan likuiditas sebagai kemampuan perusahaan memenuhi semua kewajibannya yang jatuh tempo, yang dapat diwujudkan jika jumlah aset lancar lebih besar daripada utang lancar.

Oleh karena itu, likuiditas merujuk pada kemampuan perusahaan dalam memenuhi kewajiban jangka pendeknya menggunakan aset yang tersedia secara tepat waktu. Indriastuti (2016) dan Gallizo \& Saladrigues (2016) menyatakan bahwa likuiditas berpengaruh negatif terhadap penerimaan opini audit going concern, sedangkan Aryantika \& Rasmini (2015) dan Saragih et al. (2017) memberikan kesimpulan bahwa likuiditas tidak berpengaruh pada opini audit going concern. Adanya perbedaan pengujian dalam penelitian sebelumnya, pengujian likuiditas terhadap opini audit going concern perlu untuk dilakukan kembali.

Selanjutnya, leverage merupakan ukuran tingkat beban utang yang ditanggung perusahaan dibandingkan dengan aktivanya (Kasmir, 2016). Selain itu, leverage digunakan untuk mengukur kemampuan perusahaan untuk membiayai seluruh kewajibannya, baik jangka pendek maupun jangka panjang apabila perusahaan tersebut dilikuidasi. Fahmi (2014) menyatakan bahwa leverage sebagai ukuran seberapa besar perusahaan dibiayai dengan utang. Penggunaan utang yang terlampau tinggi dapat membahayakan perusahaan karena perusahaan akan masuk dalam kategori extreme leverage yakni perusahaan terjebak dalam tingkat utang yang tinggi dan sulit untuk melepaskan beban utang tersebut.

Harjito \& Martono (2014) menyimpulkan bahwa leverage sebagai penggunaan aset dan sumber dana oleh perusahaan, dimana penggunaan aset dan dana dimaksudkan untuk mengoptimalkan keuntungan yang diterima perusahaan. Menurut Sujarweni (2017), leverage adalah rasio yang digunakan untuk mengukur kemampuan perusahaan untuk memenuhi seluruh kewajibannya baik jangka pendek maupun jangka panjang serta seberapa efektif perusahaan menggunakan sumber daya yang dimiliki.

Oleh karena itu, leverage merupakan rasio yang digunakan untuk mengukur sejauh mana aktiva perusahaan dibiayai dengan utang. Aryantika \& Rasmini (2015) menemukan bahwa 
leverage berpengaruh positif terhadap opini audit going concern, sedangkan Wulandari (2014) dan Rakatenda \& Putra (2016) menyimpulkan bahwa leverage tidak berpengaruh terhadap pemberian opini audit going concern. Perbedaan hasil pengujian leverage terhadap opini audit going concern mengakibatkan perlu pengujian kembali.

Sementara itu, financial distress merupakan suatu kondisi dimana arus kas operasi perusahaan tidak mencukupi untuk memenuhi kewajiban lancarnya dan dapat mengarah pada potensi kebangkrutan (Solikhah, 2016). Menurut Noeriyanto (2019), financial distress dapat digambarkan dari dua titik ekstrim yaitu kesulitan likuiditas jangka pendek sampai insolvabel. Indikator kesulitan keuangan dapat dilihat dari analisis aliran kas, analisis strategi perusahaan, dan laporan keuangan perusahaan.

Ellen \& Juniarti (2013) mendefinisikan financial distress sebagai suatu kondisi dimana perusahaan mengalami penyimpangan dan tekanan keuangan yang secara bertahap akan mengarah kepada kebangkrutan. Fatmawati (2017) menyatakan bahwa financial distress digambarkan sebagai ketidakmampuan perusahaan untuk membayar kewajiban finansial yang telah jatuh tempo. Oleh karena itu, financial distress risk merupakan kondisi dimana perusahaan mengalami kesulitan keuangan dan terancam mengalami kebangkrutan.

Solikhah (2016) membuktikan bahwa financial distress risk tidak terbukti berpengaruh terhadap kemungkinan penerimaan opini audit going concern, sedangkan Yuliyani \& Erawati (2017) menunjukkan bahwa financial distress risk berpengaruh negatif pada opini audit going concern. Adanya perbedaan hasil pengujian tersebut, pengujian financial distress risk terhadap opini audit going concern perlu diinvestigasi kembali.

Penelitian ini menggunakan tambahan variabel tax risk sebagai faktor determinan lainnya dalam penentuan opini audit going concern suatu perusahaan yang masih jarang digunakan dalam penelitian sebelumnya. Dengan demikian, penggunaan variabel ini dapat memberikan kontribusi dalam pengujian audit opini audit going concern. Hutchens \& Rego (2015) mendefinisikan tax risk sebagai ketidakpastian berkaitan dengan pajak yang mencakup transaksi perusahaan, operasi, keputusan pelaporan keuangan, dan reputasi perusahaan.

Ketidakpastian ini termasuk ketidakpastian dalam penerapan peraturan perpajakan, kemungkinan dilakukan audit oleh otoritas pajak, ketidakpastian akuntansi keuangan untuk pajak penghasilan dan kualitas informasi akuntansi sebagai dasar pengambilan keputusan perpajakan. Tax risk berbeda dengan tax avoidance karena tax risk mencerminkan bagaimana perusahaan dapat mempertahankan posisi pajaknya dari waktu ke waktu, sementara tax avoidance merupakan adopsi peraturan pajak yang mengurangi pembayaran pajak penghasilan perusahaan (Guenther et 
al., 2013).

Posisi pajak terkait erat dengan jumlah pembayaran pajak yang dilakukan oleh suatu perusahaan. Dengan perubahan peraturan perpajakan dan kebijakan pajak yang diambil oleh manajemen perusahaan tidak menutup kemungkinan pembayaran pajak akan berubah dari waktu ke waktu. Semakin tidak pasti tax position suatu perusahaan, maka ketidakpastian arus kas bersih masa depan perusahaan juga akan meningkat.

Data penelitian ini menggunakan data perusahaan sektor keuangan yang terdaftar di Bursa Efek Indonesia. Sampai dengan saat ini, terdapat 93 perusahaan sektor keuangan yang terdaftar di Bursa Efek Indonesia dan terbagi menjadi beberapa subsektor, meliputi bank, lembaga pembiayaan, perusahaan efek, asuransi, dan sektor lainnya.

Alasan pemilihan data penelitian ini karena keberadaan sektor ini sebagai lembaga intermediasi mempunyai peran strategis dalam perekonomian Indonesia. Stabilitas kinerja dan profil risiko perusahaan di sektor ini tidak hanya menentukan kelangsungan hidup perusahaan, tetapi juga berpengaruh terhadap kondisi perekonomian negara. Selain itu, penelitian ini difokuskan pada perusahaan yang bergerak di sektor keuangan untuk menghasilkan data yang lebih akurat berdasarkan fakta yang sudah dikemukakan sebelumnya.

\section{Tinjauan Literatur}

\section{Teori Keagenan}

Jensen \& Meckling (1976) mendeskripsikan adanya hubungan kontrak antara agent (manajemen) dan principal (pemilik). Dalam teori ini, baik principal maupun agent diasumsikan sebagai orang ekonomi rasional dan akan berusaha untuk memaksimalkan kepentingan masingmasing. Kondisi ini dapat memicu terjadinya konflik keagenan. Konflik keagenan didukung oleh adanya informasi asimetri antara agent dengan principal.

Informasi asimetri merupakan kondisi yang terjadi ketika satu pihak memiliki informasi lebih banyak dibanding pihak lainnya. Manajemen diberi wewenang oleh pemilik untuk melakukan operasional perusahaan, sehingga manajemen lebih banyak memiliki informasi mengenai perusahaan dibandingkan pemilik. Pihak ketiga yang independen dibutuhkan sebagai mediator dalam hubungan antara agent dan principal.

Agent bertugas menjalankan perusahaan dan menghasilkan laporan keuangan sebagai bentuk dari pertanggungjawaban manajemen. Laporan keuangan ini yang nantinya akan menunjukkan kinerja perusahaan dan digunakan oleh principal sebagai dasar dalam pengambilan keputusan. Dari laporan keuangan ini dapat dilihat seberapa besar kinerja perusahaan yang telah dihasilkan perusahaan. 
Agent sebagai pihak yang menghasilkan laporan keuangan mempunyai keinginan untuk mengoptimalkan kepentingannya, sehingga dimungkinkan agent melakukan manipulasi data atas kondisi perusahaan. Auditor dianggap sebagai pihak yang mampu menjembatani kepentingan principal dan agent dalammelakukan pengawasan terhadap kinerja manajemen (Solikhah, 2016).

Auditor akan menilai apakahmanajemen sebagai agen telah bertindak sesuai dengan kepentingan principal / pemilik melalui laporan keuangan. Tugas dari auditor adalah memberikan jasa untuk menilai kewajaran laporan keuangan perusahaan dengan hasil akhir adalah pemberian opini audit. Selain itu, auditor juga harus mengungkapkan permasalahan going concern yang dihadapi perusahaan apabila auditor meragukan kemampuan perusahaan dalam mempertahankan kelangsungan hidupnya.

\section{Pengembangan Hipotesis}

Going concern merupakan sebuah asumsi dalam penyusunan laporan keuangan yang mengindikasikan bahwa suatu entitas akan menjalankan operasinya dalam jangka waktu yang cukup lama untuk mewujudkan proyek, tanggung jawab, serta aktivitas-aktivitasnya (Indriastuti, 2016). Ketika suatu perusahaan dianggap mampu mempertahankan kelangsungan usahanya dalam jangka panjang dan tidak dilikuidasi dalam waktu dekat, perusahaan tersebut diasumsikan going concern. Para penyedia modal akan mempertimbangkan keputusan untuk berinvestasi salah satunya dengan melihat kemampuangoing concern perusahaan.

Salah satu indikasi perusahaan dapat mempertahankan kelangsungan usahanya adalah dengan memelihara tingkat likuiditas yang tinggi. Likuiditas menunjukkan kemampuan sebuah perusahaan dalam melunasi kewajiban jangka pendek dengan menggunakan aset lancarnya. Semakin rendah tingkat likuiditas perusahaan, maka semakin rendah juga kemampuan perusahaan tersebut dalam melunasi kewajiban jangka pendeknya dengan menggunakan aset lancar yang dimiliki perusahaan tersebut.

Sebaliknya, jika likuiditas perusahaan meningkat, maka semakin besar juga kemampuan perusahaan dalam melunasi kewajiban jangka pendeknya dengan tepat waktu. Perusahaan yang mempunyai likuiditas rendah mengindikasikan perusahaan tersebut semakin rendah juga kemampuannya dalam melunasi kewajiban jangka pendeknya dengan tepat waktu, sehingga meningkatkan potensi bagi auditor dalam menerbitkan opini audit going concern. Gallizo \& Saladrigues (2016) dan Indriastuti (2016) menemukan bahwa likuiditas berpengaruh negatif terhadap opini audit going concern.

Likuiditas yang tinggi menunjukkan kemampuan perusahaan untuk lebih dapat memenuhi kewajiban lancarnya yang akan jatuh tempo. Likuiditas yang tinggi juga menunjukkan 
keberhasilan manajemen dalam mengelola sumber daya dalam memperoleh aset lancar lebih tinggi, terlepas adanya informasi asimetri informasi. Kondisi ini menunjukkan jaminan kerbelangsungan usaha yang lebih tinggi. Oleh karena itu, tingkat likuiditas yang tinggi memungkinkan auditor tidak memunculkan opini audit going concern dalam laporan keuangan yang telah diaudit. Dengan demikian, hipotesis pertama dalam penelitian ini adalah:

$\mathrm{H}_{1}$ : Likuiditas berpengaruh negatif terhadap opini audit going concern.

Opini audit going concern merupakan suatu opini yang dikeluarkan oleh auditor untuk memberikan kepastian apakah suatu perusahaan dapat mempertahankan kelangsungan usahanya. Laporan audit sangat penting dalam suatu audit atau proses atestasi lainnya karena laporan audit memberikan informasi kepada pemakai laporan keuangan mengenai apa yang telah dilakukan oleh auditor (Arens et al., 2016). Selain opini audit terkait dengan kewajaran penyajian laporan keuangan, terdapat opini audit going concern untuk perusahaan-perusahaan yang mengalami potensi kebangkrutan. Informasi ini dianggap penting bagi stakeholder atau pemangku kepentingan terutama investor dalam pengambilan keputusan investasinya.

Terkait dengan hal tersebut, leverage dapat menjadi indikasi bahwa perusahaan mendapatkan opini audit going concern atau tidak. Leverage mencerminkan tingkat utang suatu perusahaan dan peningkatan risiko kegagalan perusahaan dalam membayar kewajiban. Namun, kondisi ini tergantung manajemen perusahaan dalam melakukan mitigasi risiko tersebut. Dalam kondisi perusahaan terdapat kegagalan keberlangsungan usaha dapat menjadi pertimbangan auditor dalam penerbitan opini audit going concern. Hal ini didukung oleh temuan Aryantika \& Rasmini (2015) bahwa leverage berpengaruh positif terhadap opini audit going concern.

Leverage menunjukkan tingkat pendanaan utang dalam struktur modal perusahaan yang lebih tinggi dibandingkan dengan sumber ekuitas. Pemilihan tingkat pendanaan utang juga didukung adanya infomasi asimetri antara manajer dan pemegang saham. Manajer dapat menentukan kebijakan pengadaan utang tanpa melalui monitoring yang dilakukan oleh pemegang saham. Adanya potensi gagal bayar akibat perusahaan memiliki utang jatuh tempo yang tinggi mengakibatkan risiko kebangkrutan yang dialami oleh perusahaan. Kondisi demikian dapat menimbulkan opini audit going concern oleh auditor dalam laporan auditnya. Dengan demikian, hipotesis kedua dalam penelitian ini adalah:

$\mathrm{H}_{2}$ : Leverage berpengaruh positif terhadap opini audit going concern.

Laporan audit yang berhubungan dengan going concern dapat memberikan peringatan awal bagi pengguna laporan keuangan guna menghindari kesalahan dalam membuat keputusan. Opini audit going concern bermanfaat bagi investor sebagai sinyal negatif tentang kelangsungan 
hidup perusahaan. Sebaliknya, opini audit non going concern dianggap sebagai sinyal positif bagi investor sebagai penanda bahwa perusahaan dalamkeadaan baik (Yuliyani \& Erawati, 2017). Dalam mengeluarkan sebuah opini, auditor harus independen dan dituntut untuk memberikan opini audit secara profesional karena opini tersebut berkaitan erat dengan kelangsungan hidup suatu perusahaan.

Salah satu yang menjadi indikasi adanya opini audit going concern adalah financial distress risk, yang dihadapi suatu perusahaan merupakan indikator perusahaan tersebut akan mengalami kebangkrutan. Pada tahap ini perusahaan berpotensi mengalami kerugian dalam jangka waktu lama dan terus-menerus sebelum terjadi kebangkrutan (Nugroho et al., 2018). Ketika terjadi financial distress atau kesulitan keuangan pada perusahaan, maka perusahaan tersebut berpeluang untuk memperoleh opini audit going concern dari auditor karena perusahaan tersebut diragukan kelangsungan usahanya dalam jangka pendek maupun jangka panjang. Berdasarkan uraian tersebut, maka hipotesis ketiga dalam penelitian ini adalah:

$\mathrm{H}_{3}$ : Financial distress berpengaruh positif terhadap opini audit going concern.

Informasi going concern suatu perusahaan merupakan merupakan informasi yang penting bagi investor dalam melakukan penilaian terkait dengan kemampuan perusahaan dalam mempertahankan usahanya (Ginting \& Tarihoran, 2017). Pemberian opini going concern menjadi salah satu aspek penting bagi manajemen perusahaan terutama bagi perusahaan yang terdaftar dalam pasar modal. Sebagai risiko yang tidak sistematis, tax risk merupakan risiko yang dapat dikelola oleh perusahaan namun dapat membahayakan perusahaan jika tidak dikelola dengan baik (Hidayat, 2015). Tax risk merupakan salah satu risiko yang harus dihindari oleh perusahaan karena dapat menyebabkan ketidakpercayaan investor terhadap kinerja perusahaan dalam mematuhi peraturan perpajakan. Semakin tinggi tax risk, maka semakin besar ketidakpastian arus kas bersih masa depan perusahaan yang dianggap sebagai suatu sinyal bahwa perusahaan akan menghadapi masalah yang dapat mengganggu kelangsungan usahanya.

$\mathrm{H}_{4}$ : Tax risk berpengaruh positif terhadap opini audit going concern.

\section{Metode Penelitian}

Penelitian ini dilakukan dengan menggunakan metode kuantitatif. Jenis data yang akan diolah dalam penelitian ini adalah data sekunder berupa laporan keuangan perusahaan sektor keuangan yang terdaftar di Bursa Efek Indonesia (BEI) dari tahun 2013 sampai dengan tahun 2019 yang diperoleh dari website resmi BEI (www.idx.co.id). Sampel data yang digunakan dalam penelitian ini adalah data panel (pooled data), yakni data dalam satu cross sectional unit yang diobservasi dalam beberapa rentang waktu (time series). 
Populasi dalam penelitian ini adalah seluruh perusahaan sektor keuangan yang terdaftar di Bursa Efek Indonesia sampai dengan 31 Desember 2019. Pengambilan sampel yang digunakan dalam penelitian ini adalah teknik purposive sampling yang merupakan teknik pengambilan sampel sumber data dengan kriteria tertentu. Kriteria pertama adalah perusahaan terdaftar di Bursa Efek Indonesia dengan klasifikasi sektor keuangan. Kedua, perusahaan telah terdaftar di Bursa Efek Indonesia dengan tanggal pencatatan sebelum 1 Januari 2013.

Perhitungan variabel tax risk membutuhkan data laporan keuangan dari tahun t-4 hingga $\mathrm{t}$ tahun sehingga jika laporan keuangan perusahaan yang digunakan sebagai sampel adalah tahun 2017-2019, maka dibutuhkan data tambahan berupa laporan keuangan tahun 2013-2015. Ketiga, perusahaan tersebut memiliki laporan keuangan yang telah diaudit oleh auditor eksternal selama tahun 2017-2019 dengan memuat informasi yang lengkap untuk menganalisis variabel, termasuk informasi mengenai kemampuan going concern perusahaan. Total sampel yang digunakan dalam penelitian ini berjumlah 84 observasi.

Penelitian ini menggunakan opini audit going concern sebagai variabel dependen, sedangkan variabel independennya terdiri dari likuiditas, leverage, financial distress risk, dan tax risk. Selain itu, penelitian ini juga menggunakan variabel kontrol yakni profitabilitas. Opini audit going concern dalam penelitian ini diukur dengan variabel dummy merujuk pada Yuliyani dan Erawati (2017). Kategori 1 untuk perusahaan yang menerima opini audit going concern dan kategori 0 untuk perusahaan yang menerima opini audit non going concern.

Variabel likuiditas pada penelitian ini dihitung dengan proksi current ratio sebagaimana digunakan oleh Indriastuti (2016) dan Lubis (2019). Menurut Kasmir (2016), current ratio merupakan rasio untuk mengukur kemampuan perusahaan dalam memenuhi kewajiban jangka pendeknya atau utang yang segera jatuh tempo pada saat ditagih secara keseluruhan. Dengan kata lain, rasio ini menunjukkan seberapa banyak aktiva lancar yang tersedia untuk menutupi kewajiban jangka pendek atau utang yang segera jatuh tempo. Rumus yang digunakan untuk menghitung current ratio adalah sebagai berikut:

\section{Current Ratio $=$ Aktiva Lancar $($ Current Asset $)$}

\section{Utang Lancar (Current Liabilities)}

Leverage dalam penelitian ini diproksikan dengan Debt to Equity Ratio sebagaimana digunakan oleh Wulandari (2014). Menurut Kasmir (2016), Debt to Equity Ratio (DER) merupakan rasio yang digunakan untuk mengukur seberapa besar beban utang yang harus ditanggung perusahaan dalam rangka pemenuhan modal. Tingginya rasio ini menunjukkan bahwa struktur modal lebih banyak memanfaatkan utang dibandingkan ekuitas. Hal ini mencerminkan 
solvabilitas perusahaan semakin rendah dan meningkatkan risiko perusahaan mengalami financial distress (kesulitan keuangan). Rumus yang digunakan untuk menghitung rasio Debt to Equity Ratio adalah sebagai berikut :

\section{Debt to Equity Ratio = $\underline{\text { Total Utang }(\text { Total Liabilities) }}$ \\ Total Ekuitas (Total Equity)}

Financial distress risk diukur dengan menggunakan model prediksi kebangkrutan Altman's Z-score Model mengikuti Yuliyani \& Erawati (2017). Model ini dianggap paling akurat dalam memprediksi kegagalan usaha. Nilai Z-Score yang dikembangkan Altman, yaitu:

$$
\mathrm{Zi}=6,56 \mathrm{X} 1+3,26 \mathrm{X} 2+6,72 \mathrm{X} 3+1,05 \mathrm{X} 4
$$

Dengan keterangan sebagai berikut:

$$
\begin{aligned}
& \text { X1 = Current Assets }- \text { Current Liabilities / Total Assets } \\
& \text { X2 = Retained Earnings / Total Assets } \\
& \text { X3 = Earnings Before Interest and Taxes / Total Assets } \\
& \text { X4 = Book Value of Equity / Book Value of Debt } \\
& \mathrm{Zi}=\text { Nilai Z-Score }
\end{aligned}
$$

Tax risk pada penelitian ini diproksikan dengan standar deviasi cash ETR tahunan yang juga digunakan dalam penelitian Drake et al. (2019). Pengukuran ini mampu menggambarkan fluktuasi ETR yang disebabkan oleh strategi pajak yang nantinya akan dilakukan pemeriksaan oleh otoritas pajak. Hasil pengukuran ini akan menunjukkan bahwa jika semakin besar standar deviasi yang dihasilkan, maka risiko pajak perusahaan tersebut semakin besar. Periode pengukuran yang diperlukan yakni dari periode $\mathrm{t}-4$ hingga $\mathrm{t}$ tahun. Pengukuran tax risk menggunakan standar deviasi cash ETR yang dirumuskan sebagai berikut:

Tax $_{\text {Risk }}, t,=$ standar deviasi tahunan dari Cash ETR perusahaan i pada tahun $\mathrm{t}$

\section{Keterangan:}

Cash ETR = jumlah pembayaran pajak secara kas selama lima tahun terakhir jumlah laba sebelum pajak selama 5 tahun terakhir

Profitabilitas dalam penelitian ini diproksikan dengan menggunakan Return on Asset (ROA) sebagaimana digunakan oleh Rakatenda \& Putra (2016). ROA merupakan rasio yang mengukur tingkat pengembalian laba bersih setelah pajak terhadap total aset. ROA berfungsi untuk mengukur efektifitas perusahaan dalam menghasilkan laba dengan memanfaatkan aset yang dikuasainya (Putranto, 2018). Semakin tinggi nilai ROA mencerminkan semakin baik kinerja perusahaan dalam memperoleh laba dan meminimalisasi diterbitkannya opini audit going concern dari auditor. Rumus yang digunakan untuk menghitung ROA adalah sebagai berikut: 


\section{Return on Asset $(\mathrm{ROA})=\underline{\text { Laba Bersih setelah Pajak }}$ \\ Total Aset}

Pengujian hipotesis dalam penelitian ini menggunakan analisis regresi logistik (logistic regression) dengan memanfaatkan program/aplikasi IBM Statistical Package for the Social Sciences (SPSS) 24. Model penelitian utama pada penelitian ini adalah sebagai berikut:

$\mathrm{OAGC}_{i t}=\alpha_{0}+\alpha_{1} \mathrm{CR}_{\mathrm{it}}+\alpha_{2} \mathrm{DER}_{\mathrm{it}}+\alpha_{3} \mathrm{ZSCORE}_{\mathrm{it}}+\alpha_{4} \mathrm{CETR}_{-} \mathrm{VOL}_{\mathrm{it}}+\alpha_{5} \mathrm{ROA}_{\mathrm{it}}+\varepsilon_{\mathrm{it}}$

Keterangan :

$\mathrm{OAGC}_{\mathrm{it}} \quad=$ Opini Audit Going Concern perusahaan i pada tahun $\mathrm{t} \alpha_{0}=$ konstanta

$\mathrm{CR}_{\mathrm{it}} \quad=$ current ratio perusahaan $\mathrm{i}$ pada tahun $\mathrm{t}$

$\mathrm{DER}_{\mathrm{it}} \quad=$ debt to equity ratio perusahaan i pada tahun $\mathrm{t}$

ZSCORE $_{\text {it }}=$ Altman Z-score perusahaan i pada tahun $\mathrm{t}$

CETR_VOL it $=$ volatilitas cash ETR perusahaan i pada tahun $\mathrm{t}$

$\mathrm{ROA}_{\mathrm{it}} \quad=$ return on asset perusahaan i pada tahun $\mathrm{t}$

$\varepsilon_{\mathrm{it}} \quad=$ nilai residu dari persamaan regresi

\section{Hasil dan Pembahasan}

Data yang digunakan dalam penelitian ini adalah data laporan keuangan perusahaan sektor keuangan yang terdaftar di Bursa Efek Indonesia dengan kriteria-kriteria sebagai berikut:

Tabel 1 Hasil Pemilihan Sampel Penelitian

\begin{tabular}{lrl}
\hline \multicolumn{1}{c}{ Kriteria } & Jumlah & Ukuran \\
\hline Perusahaan terdaftar di Bursa Efek Indonesia dengan & 90 & Perusahaan \\
klasifikasi sektor keuangan & & \\
Perusahan yang terdaftar di BEI setelah 1 Januari 2013 & $(26)$ & Perusahaan \\
Elemen dan/atau informasi dalam Laporan Keuangan tidak & $(36)$ & Perusahaan \\
lengkap & & \\
Total perusahaan yang digunakan dalam sampel penelitian & 28 & Perusahaan \\
Jumlah tahun observasi & 3 & Tahun \\
Total observasi & 84 & Observasi \\
\hline
\end{tabular}

Sumber: data diolah

Selanjutnya, hasil analisis statistik deskriptif dari data masing-masing variabel yang digunakan dalam penelitian ini disajikan pada tabel berikut: 


\begin{tabular}{lllllll}
\hline \hline \multicolumn{7}{c}{ Tabel 2 Statistik Deskriptif Variabel } \\
\hline Mean & OAGC & CR & DER & ZSCORE & CETRV & ROA \\
Median & 0.0714 & 3.3955 & 3.5274 & 4.7726 & 0.1677 & 0.0139 \\
Maximum & 0 & 2.0238 & 2.4904 & 4.0076 & 0.0949 & 0.0115 \\
Minimum & 0 & 19.7659 & 14.7485 & 15.0241 & 1.1491 & 0.1036 \\
\hline \hline Std. Dev. & 0.2591 & 3.8251 & 3.1899 & 3.2665 & 0.2036 & 0.0441 \\
Obs. & 84 & 84 & 84 & 84 & 84 & 84 \\
\hline
\end{tabular}

Sumber: data diolah

Uji koefisien determinasi pada analisis regresi logistik dapat dilihat pada nilai Nagelkerke $R$ Square. Nilai Nagelkerke $R$ Square dari hasil pengolahan data dengan SPSS menunjukkan hasil sebesar 0,583 yang berarti bahwa variabilitas variabel dependen yang dapat dijelaskan oleh variabel independen dalam penelitian ini adalah sebesar 58,3\%. Sisanya sebesar $41,7 \%$ dijelaskan oleh variabel lain di luar model penelitian ini.

Tabel 3 Uji Koefisien Determinasi

\begin{tabular}{lccc}
\hline Step & -2 Log likelihood & Cox \& Snell R Square & Nagelkerke R Square \\
1 & $20.780^{\mathrm{a}}$ & 0.235 & 0.583 \\
\hline \multicolumn{2}{c}{ Sumber: data diolah }
\end{tabular}

Selanjutnya, hasil pengujian hipotesis dalam penelitian ini adalah sebagai berikut:

Tabel 4 Hasil Pengujian Hipotesis

\begin{tabular}{cccccc}
\hline Variable & B & Wald & Df & Sig. & \\
\hline Constant & 0.808 & 0.103 & 1 & 0.374 & $* *$ \\
CR & -3.176 & 4.119 & 1 & 0.021 & $* * 198$ \\
DER & -0.445 & 0.725 & 1 & 0.198 \\
ZSCORE & 0.533 & 6.527 & 1 & 0.005 & $* * *$ \\
CETRV & 2.811 & 1.483 & 1 & 0.112 & \\
ROA & -8.961 & 0.539 & 1 & 0.232 & \\
\hline
\end{tabular}

Sumber: data diolah

\section{Pengaruh likuiditas terhadap opini audit going concern}

Hasil pengujian hipotesis menunjukkan bahwa likuiditas berpengaruh negatif terhadap penerimaan opini audit going concern. Hasil penelitian ini sejalan dengan Gallizo \& Saladrigues (2016) dan Indriastuti (2016), namun tidak sejalan dengan hasil yang diperoleh Aryantika \& Rasmini (2015) dan Saragih et al. (2017). Perbedaan hasil penelitian tersebut dapat disebabkan oleh perbedaan sampling yang digunakan. Sampel pada penelitian ini menggunakan perusahaan sektor keuangan yang memiliki karakteristik berupa proporsi utang yang lebih dominan. 
Hampir semua laporan keuangan perusahaan sektor keuangan tidak membedakan secara jelas klasifikasi utang jangka pendek dan utang jangka panjang di neracanya. Untuk keperluan penelitian ini, beberapa utang seperti tabungan nasabah dan estimasi klaim asuransi dianggap memiliki potensi pelunasan yang harus dipenuhi dalam jangka waktu kurang dari satu tahun sehingga diklasifikasikan sebagai utang jangka pendek. Oleh karena itu, perbedaan interpretasi utang jangka pendek di perusahaan sektor keuangan dapat mengakibatkan perbedaan hasil penelitian untuk perusahaan di sektor non keuangan.

Hasil penelitian ini menunjukkan bahwa semakin kecil likuiditas, maka sumber daya aset lancar yang tersedia semakin sedikit dan berpotensi tidak mampu mencukupi utang yang akan jatuh tempo dalam jangka waktu kurang dari 12 bulan seperti deposito, obligasi, tabungan, dan estimasi klaim asuransi. Ketika perusahaan tidak mampu memenuhi kewajiban jangka pendeknya akan berakibat pada penghapusan aset non jangka pendek untuk menutupi kekurangannya.

Penghapusan aset non jangka pendek seperti aset tetap akan memberikan dampak terhadap operasi perusahaan. Hal tersebut tentunya menjadi perhatian bagi auditor karena lemahnya current ratio dapat berdampak pada meningkatnya kesangsian/keraguan terhadap kemampuan keberlangsungan hidup perusahaan. Auditor merasa perlu untuk memberikan opini going concern sebagai pertimbangan bagi pengguna laporan keuangan dalam mempertahankan investasinya di perusahaan tersebut.

Berkaitan dengan standar audit, hasil penelitian ini sesuai dengan Pernyataan Standar Audit Nomor 30 tentang kondisi yang perlu dipertimbangkan oleh auditor dalam menilai kelangsungan hidup suatu perusahaan, dimana dalam salah satu poinnya disebutkan mengenai adanya petunjuk tentang kemungkinan suatu perusahaan mengalami kesulitan keuangan dalam bentuk kegagalan dalam memenuhi kewajiban utangnya, restrukturisasi utang, atau penjualan sebagian besar aktiva.

\section{Pengaruh leverage terhadap opini audit going concern}

Hasil pengujian hipotesis menunjukkan bahwa leverage tidak berpengaruh terhadap opini audit going concern. Hasil penelitian ini didukung oleh penelitian sebelumnya yang dilakukan oleh Wulandari (2014) dan Rakatenda \& Putra (2016). Sehubungan dengan objek penelitian yang merupakan sektor keuangan dimana proses bisnis utama perusahaan berkaitan dengan penyimpanan uang pihak ketiga yang menimbulkan cost of capital dalam bentuk pembayaran bunga, maka sebagian besar perusahaan memiliki leverage yang tinggi dilihat dari hasil perhitungan Debt to Equity Ratio.

Auditor menganggap bahwa meskipun perusahaan memiliki sumber pendanaan yang 
cenderung berasal dari utang, sepanjang cost of capital yang timbul masih dapat dilunasi oleh perusahaan, maka tidak menjadi perhatian bagi auditor untuk menerbitkan opini going concern. Perusahaan masih dianggap memiliki tingkat kredibilitas tinggi yang membuat investor atau kreditur percaya untuk menyalurkan dana ke perusahaan tersebut dan membuat auditor menurunkan kesangsian dalam menilai keberlangsungan hidup perusahaan. Selain itu, perusahaan perbankan memiliki sistem pengelolaan utang yang baik dengan karakteristik struktur modal dengan tingkat utang yang tinggi. Oleh karena itu, utang yang tinggi bukan menjadi indikator dalam menentukan tingkat keberlangsungan perusahaan di masa depan.

\section{Pengaruh financial distress terhadap opini audit going concern}

Hasil pengujian hipotesis menunjukkan bahwa financial distress berpengaruh positif terhadap penerimaan opini audit going concern. Penelitian ini memberikan hasil yang berbeda dengan penelitian yang dilakukan oleh Solikhah (2016) dan Yuliyani \& Erawati (2017). Ketika perusahaan mengalami financial distress, maka perusahaan tersebut berpeluang mendapatkan opini audit going concern dari auditor karena terdapat /keraguan tentang kemampuan entitas untuk mempertahankan kelangsungan hidupnya.

Hasil penelitian ini telah sesuai dengan Pernyataan Standar Audit Nomor 30 tentang kondisi yang perlu dipertimbangkan oleh auditor dalam menilai kelangsungan hidup suatu perusahaan, dimana dalam salah satu poinnya disebutkan mengenai adanya kemungkinan suatu perusahaan mengalami kesulitan keuangan seperti membukukan rugi operasional dan arus kas negatif dariaktivitas operasinya.

Kondisi financial distress menunjukkan bahwa perusahaan tidak mampu untuk membayar kewajiban keuangan yang telah jatuh tempo (Fatmawati, 2017). Kondisi ini memicu adanya tuntutan dari pihak kreditor terkait dengan kepailitan perusahaan yang berarti perusahaan dapat berhenti beroperasi (Hidayah \& Firmansyah, 2020). Pemberian opini audit going concern merupakan indikasi bagi perusahaan untuk memperbaiki kinerjanya, sehingga terdapat kepercayaan pemangku kepentingan seperti kreditor terkait dengan keberlangsungan perusahaan di masa depan, termasuk kesempatan untuk melakukan restrukturisasi utang jatuh tempo kepada kreditor.

\section{Pengaruh tax risk terhadap opini audit going concern}

Hasil pengujian hipotesis menunjukkan bahwa tax risk tidak berpengaruh terhadap opini audit going concern. Temuan ini mengindikasikan bahwa auditor tidak menjadikan tax risk sebagai faktor krusial dalam memberikan opini audit going concern. Tax risk hanya mencerminkan bagaimana perusahaan dapat mempertahankan posisi pajaknya (tax position) dari 
waktu ke waktu, bukan menandakan ketidakmampuan perusahaan dalam memenuhi kewajiban perpajakannya.

Tax position yang berkaitan dengan jumlah pembayaran pajak dapat mengalami perubahan dengan berbagai faktor yang memengaruhinya, baik faktor eksternal maupun faktor internal. Berdasarkan kondisi yang terjadi di Indonesia, faktor eksternal perusahaan seperti kondisi ekonomi dan politik lebih dominan dibandingkan dengan faktor internal dalam membentuk ketidakpastian berkaitan dengan pajak.

Tax risk menunjukkan ketidakpastian dalam penerapan peraturan perpajakan, kemungkinan dilakukan audit oleh otoritas pajak, ketidakpastian akuntansi keuangan untuk pajak penghasilan dan kualitas informasi akuntansi sebagai dasar pengambilan keputusan perpajakan (Guenther et al., 2013). Adanya risiko pajak bukan menjadi indikasi perusahaan mengalami permasalahan dengan keberlangsungan usaha perusahaan di masa depan. Tax risk lebih mencerminkan posisi pajak terkait dengan jumlah pembayaran pajak yang dilakukan oleh suatu perusahaan yang diakibatkan oleh peraturan perpajakan dan kebijakan pajak yang diambil oleh manajemen. Namun, kondisi ini tidak mengakibatkan auditor untuk memberikan opini audit going concern kepada perusahaan yang diauditnya.

\section{Kesimpulan}

Penelitian ini menyimpulkan bahwa tingkat likuiditas perusahaan yang semakin tinggi menunjukkan perusahaan mampu memenuhi kewajiban lancarnya, sehingga perusahaan memiliki tingkat kepastian keberlangsungan usaha yang tinggi. Sementara itu, auditor menilai perusahaan yang memiliki kecenderungan sumber pendanaan berasal dari utang, tidak akan memengaruhi penerimaan opini audit going concern sepanjang cost of capital yang timbul masih dapat dilunasi oleh perusahaan terkait.

Selanjutnya, kesulitan keuangan yang dialami perusahaan ditandai dengan adanya rugi operasional dan arus kas negatif dari aktivitas operasi meningkatkan kemungkinan auditor untuk memberikan opini audit going concern terhadap laporan keuangan perusahaan. Penelitian ini juga memberikan kontribusi dalam pengujian tax risk terhadap opini audit going concern yang masih jarang dilakukan dalam penelitian sebelumnya.

Hasil pengujian dalam penelitian ini menunjukkan bahwa opini audit going concern tidak dipengaruhi oleh tax risk. Tax risk hanya mencerminkan bagaimana perusahaan dapat mempertahankan posisi pajaknya dari waktu ke waktu, bukan menandakan ketidakmampuan perusahaan dalam memenuhi kewajiban perpajakannya.

Penelitian ini juga memiliki beberapa keterbatasan. Pertama, penelitian terhadap opini 
audit going concern ini hanya menggunakan variabel keuangan yang mencerminkan kinerja internal perusahaan, sedangkan keberlangsungan usaha juga dapat dipengaruhi oleh faktor eksternal seperti kebijakan pemerintah, kondisi ekonomi, persaingan usaha, dan auditor client tenure (lama perikatan audit).

Kedua, periode observasi hanya terbatas pada tiga periode pelaporan keuangan (20172019), sehingga belum dapat menentukan kecenderungan (trend) terhadap penerimaan opini audit going concern oleh auditor dalam jangka panjang. Penelitian selanjutnya diharapkan dapat menggunakan time-horizon yang lebih lama untuk mendapatkan hasil pengujian yang lebh baik. Selain itu, penelitian ini hanya terbatas pada perusahaan sektor keuangan yang terdaftar di Bursa Efek Indonesia sebagai populasi dalam pengambilan sampel.

Penelitian selanjutnya dapat dilakukan pada sektor usaha lainnya, sehingga mampu menggambarkan tren opini audit going concern dalam ruang lingkup sektor usaha yang lebih luas, termasuk pengujian tax risk yang masih jarang dilakukan dalam penelitian sebelumnya.

Hasil penelitian ini dapat menjadi bahan pertimbangan bagi Otoritas Jasa Keuangan dalam melakukan pengawasan terhadap kualitas jasa keuangan perusahaan yang bergerak di sektor keuangan khususnya terkait dengan dukungan atas perlindungan investor. Selain itu, penelitian ini dapat dijadikan rujukan bagi investor dan calon investor untuk lebih memperhatikan opini audit going concern dalam laporan keuangan perusahaan dan faktor - faktor yang mempengaruhinya sehingga mampu mengambil keputusan dengan tepat terkait investasi.

\section{DAFTAR PUSTAKA}

Altman, E. I. (1974). Financial ratios, discriminant analysis and the prediction of corporate bankruptcy. The journal of finance, 23(4), 589-609.

Arens, A. A., Elder, R. J., \& Beasley, M. S. (2014). Auditing and Assurance Service : An Integrated approach, sixteenth edition. New York: Pearson.

Aryantika, N. P. P., \& Rasmini, N. K. (2015). Profitabilitas, Leverage, Prior Opinion Dan Kompetensi Auditor Pada Opini Audit Going Concern. E-Jurnal Akuntansi Universitas Udayana, 2, 414-25.

Drake, K. D., Lusch, S. J., \& Stekelberg, J. (2019). Does tax risk affect investor valuation of tax avoidance?. Journal of Accounting, Auditing \& Finance, 34(1), 151-176.

Ellen, E. (2013). Penerapan Good Corporate Governance, Dampaknya Terhadap Prediksi Financial Distress Pada Sektor Aneka Industri Dan Barang Konsumsi. Business Accounting Review, 1(2), 1-13. 
Fahmi, I. (2014). Analisis Laporan Keuangan. Bandung: CV Alfabeta.

Fatmawati, A. (2017). Faktor-Faktor yang Mempengaruhi Financial Distress (Studi pada Perusahaan Manufaktur di BEI). Jurnal Ilmu dan Riset Akuntansi (JIRA), 6(10).

Firmansyah, A., \& Muliana, R. (2018). The effect of tax avoidance and tax risk on corporaterisk. Jurnal Keuangan dan Perbankan, 22(4), 643-656.

Gallizo, J. L., \& Saladrigues, R. (2016). An analysis of determinants of going concern auditopinion: Evidence from Spain stock exchange. Intangible Capital, 12(1), 1-16.

Ginting, S., \& Tarihoran, A. (2017). Faktor-faktor yang mempengaruhi pernyataan goingconcern. Jurnal Wira Ekonomi Mikroskil, 7(1), 9-20.

Guenther, D. A., Matsunaga, S. R., \& Williams, B. M. (2013). Tax avoidance, tax aggressiveness, tax risk and firm risk. Unpublished paper, 305-360.

Hani, S. (2015). Teknik Analisa Laporan Keuangan. Medan: In Media.

Harjito, D. A., \& Martono, S. U. (2014). Manajemen Keuangan Edisi Kedua. Yogyakarta: Ekonisia.

Hidayah, N., \& Firmansyah, A. (2020). Implementasi likuidasi korporasi di Indonesia: kajian akuntansi dan yuridis. Jurnal Ilmiah Wahana Akuntansi, 15(2), 184-196

Hidayat, N. (2015). Corporate Tax Risk Management. Jakarta: Elex Media Komputindo. Hutchens, M., \& Rego, S. O. (2015). Does greater tax risk lead to increased firm risk?.

Financial Accounting E-Journal.

Indriastuti, M. (2016). Pengaruh Profitabilitas dan Likuiditas terhadap Penerimaan OpiniAudit Going Concern. Fokus Ekonomi: Jurnal Ilmiah Ekonomi, 11(2).

Institut Akuntan Publik Indonesia. (2011). Penyataan Standar Auditing (PSA) No. 30 tentang Pertimbangan Auditor atas Kemampuan Entitas dalam Mempertahankan Kelangsungan Hidupnya. Jakarta: IAPI.

Islami, M. A., \& Isynuwardhana, D. (2019). Pengaruh Leverage dan Likuiditas terhadap Profitabilitas (Studi pada Perusahaan Manufaktur Sub Sektor Tekstil dan Garment yang Terdaftar di Bursa Efek Indonesia Periode 2013-2018). eProceedings of Management, 6(2).

Jensen, M. C., \& Meckling, W. H. (1976). Theory of the firm: Managerial behavior, agency costs and ownership structure. Journal of financial economics, 3(4), 305-360.

Kasmir. (2016). Analisis Laporan Keuangan. Jakarta: PT Raja Grafindo Persada.

Lubis, S. A. M. (2019). Pengaruh current ratio, net profit margin, opini audit sebelumnya, serta pertumbuhan perusahaan terhadap opini audit going concern (Studi Pada Perusahaan Sektor Keuangan yang Terdaftar di BEI Periode 2015-2017). Skripsi: Fakultas 
Ekonomi dan Bisnis, Universitas Sumatera Utara.

Ningtias, M. A., \& Yustrianthe, R. H. (2016). Studi Empiris Faktor yang Mempengaruhi Penerimaan Opini Audit Going Concern. Jurnal Akuntansi, 5(1), 42-68.

Noeriyanto, M. H. R. (2019). Pengaruh Profitabilitas, Leverage, dan Likuiditas untuk Memprediksi Financial Distress pada Sektor Pertambangan yang Terdaftar di BEI 2013-2017 (Doctoral dissertation, STIE Perbanas Surabaya).

Nugroho, L., Nurrohmah, S., \& Anasta, L. (2018). Faktor-Faktor yang Mempengaruhi Opini Audit Going Concern. Jurnal Sikap, 2(2), 96-111.

Putranto, P. (2018). Faktor-faktor yang Berdampak pada Penerimaan Opini Audit Going Concern. Jurnal Online Insan Akuntan, 3(2), 207-218.

Rahadiyan, I. (2016). Peran dan tanggung jawab lembaga penjamin simpanan dalam penanganan dan penyelamatan bank gagal berdampak sistemik. Jurnal Hukum IUS QUIA IUSTUM, 23(1), 23 - 41

Rakatenda, G. N., \& Putra, I. W. (2016). Opini Audit Going Concern dan Faktor-Faktor yang Mempengaruhinya. E-Jurnal Akuntansi Universitas Udayana, 16(2), 1347-1375.

Saragih, F., Lubis, P. K. D., \& Al Khair, P. (2017). Effect of Profitability, Liability and Quality of Auditors Audit Opinion, Going Concern in Food and Drink Listed in Indonesia Stock Exchange (IDX). Proceeding 3rd Sriwijaya Economics, Accountingand Business Conference.

Saragih, H. P. (2019). Terungkap Ini Penyebab Masalah Kronis di Bank Muamalat. Diakses di https://www.cnbcindonesia.com/market/20191115093424-17-115443/terungkap-inipenyebab-masalah-kronis-di-bank-muamalat (diakses pada 17 April 2020).

Solikhah, B. (2016). Pertimbangan Auditor dalam Memberikan Opini Audit Going Concern.

EKUITAS (Jurnal Ekonomi dan Keuangan), 20(2), 129-150.

Sujarweni, V. W. (2017). Analisis Laporan Keuangan. Yogyakarta: Pustaka Baru Press. Wulandari, S. (2014). Analisis Faktor-Faktor yang Mempengaruhi Auditor dalam

Memberikan Opini Audit Going Concern. E-Jurnal Akuntansi, 6(3), 531-558.

Yuliyani, N. M. A., \& Erawati, N. M. A. (2017). Pengaruh Financial Distress, Profitabilitas, Leverage Dan Likuiditas Pada Opini Audit Going Concern. E-Jurnal Akuntansi Universitas Udayana, 19(2), 1490-1520. 